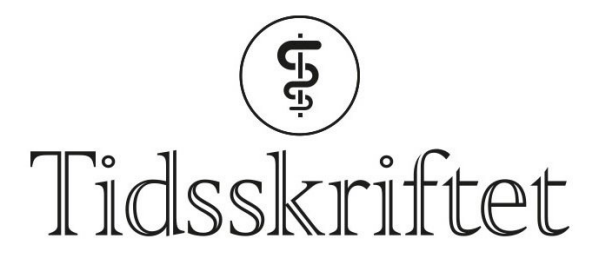

DEN NORSKE LEGEFORENING

\title{
Jernavleiring i motorisk korteks ved amyotrofisk lateral sklerose
}

MEDISINEN I BILDER

\section{MORTEN HORN}

E-post: morten_horn@hotmail.com Nevrologisk avdeling

Oslo universitetssykehus, Ullevål

Morten Horn er ph.d., spesialist i nevrologi, overlege og lege i ALS-teamet. Forfatteren har fylt ut ICMJE-skjemaet og oppgir ingen interessekonflikter.

\section{SHEIK RYAZ YASEEN}

Nevrologisk avdeling

Oslo universitetssykehus, Ullevål

Sheik Ryaz Yaseen er spesialist i nevrologi, overlege og lege i ALS-teamet.

Forfatteren har fylt ut ICMJE-skjemaet og oppgir ingen interessekonflikter.

\section{THOMAS ALEXANDER SKOG}

Nevroradiologisk seksjon

Oslo universitetssykehus, Ullevål

Thomas Alexander Skog er spesialist i radiologi og overlege.

Forfatteren har fylt ut ICMJE-skjemaet og oppgir ingen interessekonflikter.

\section{MANINDER SINGH CHAWLA}

Nevroradiologisk seksjon

Oslo universitetssykehus, Ullevål

Maninder Singh Chawla er spesialist i radiologi og overlege.

Forfatteren har fylt ut ICMJE-skjemaet og oppgir ingen interessekonflikter.
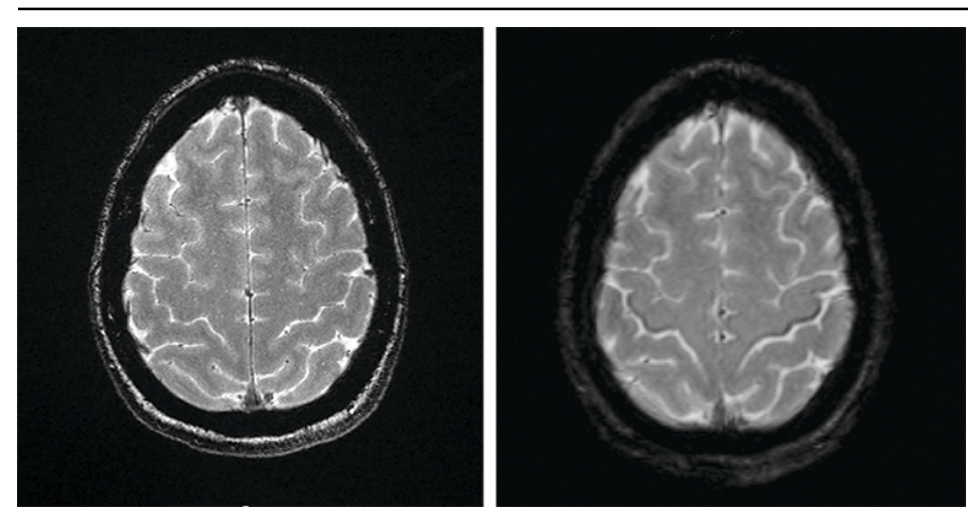

Susceptibilitetsvektede MR-bilder (SWI-magnitude) av hjernen (bildet til høyre) viser lavsignal forenlig med jernavleiring i bakre deler av gyrus precentralis tilsvarende motorisk korteks på begge sider hos en pasient i 50-årene med amyotrofisk lateral sklerose (ALS) $(1,2)$. 
Det såkalte svart bånd-tegnet (motor band sign / black ribbon sign) synes ikke på MR-bildene tatt ett år tidligere (bildet til venstre).

Pasienten debuterte med bulbære symptomer i form av svelg- og talevansker. Hun utviklet et halvt år før MR-bildene ble tatt et stormende klinisk bilde av uttalt tetraspastisitet, som responderte godt på peroral behandling med baklofen.

Den kliniske ALS-diagnosen kan støttes av forskningskriterier. El Escorial-kriteriene krever bevis for affeksjon av både øvre og nedre motonevroner. Kriteriene har lav sensitivitet, særlig tidlig i forløpet, noe som kan bidra til usikkerhet og forsinket diagnose. Awajikriteriene er mer sensitive for påvisning av nedre motornevronaffeksjon, men sentrale tegn (temposvikt, spastisitet og hyperrefleksi) kan skjules av de perifere utfallene.

Ved utredning av mistenkt amyotrofisk lateral sklerose har MR-undersøkelse til nå blitt brukt differensialdiagnostisk med tanke på andre årsaker til øvre motornevrontegn (for eksempel cervikal myelopati og cerebrovaskulære forandringer). Kasuistikken illustrerer at magnetisk resonanstomografi kan vise spesifikke funn ved amyotrofisk lateral sklerose, som jernavleiring i gyrus precentralis. I en prospektiv studie fra Mexico hadde $92 \%$ av 38 ALS-pasienter "svart bånd-tegn" på tre tesla-MR-undersøkelser (1). Ved Oslo universitetssykehus har vi fra 2020 begynt å gjøre MR med SWI-sekvenser rutinemessig ved utredning av amyotrofisk lateral sklerose.

\section{LITTERATUR:}

1. Boll MC, Marrufo Meléndez OR, Rios C et al. Is the hyperintensity in motor cortex the hallmark of amyotrophic lateral sclerosis? Can J Neurol Sci 2019; 46: 166-73. [PubMed][CrossRef]

2. Roeben B, Wilke C, Bender B et al. The motor band sign in ALS: presentations and frequencies in a consecutive series of ALS patients. J Neurol Sci 2019; 406: 116440. [PubMed][CrossRef]

Publisert: 12. mars 2021. Tidsskr Nor Legeforen. DOI:10.4045/tidsskr.20.0632

Mottatt 11.8.2020, første revisjon innsendt 17.11.2020, godkjent 13.1.2021.

(C) Tidsskrift for Den norske legeforening 2020. Lastet ned fra tidsskriftet.no 